\title{
REGISTRO DE ESPÉCIES DE MACROBRACHIUM SPENCE BATE, 1868 (DECAPODA: CARIDEA: PALAEMONIDAE) EM CURSO D'ÁGUA NA PRAIA DO FÉLIX, UBATUBA, SP
}

\author{
Mollemberg, M. ${ }^{1,2,}$; Lianos, L. ${ }^{1,2} \&$ Santana, W. ${ }^{1,2}$ \\ ${ }^{1}$ Universidade Estadual Paulista Júlio de Mesquita Filho (UNESP), Campus Botucatu, Pós-Graduação em Zoologia. \\ ${ }^{2}$ Universidade do Sagrado Coração (USC), Campus Bauru, Laboratório de Sistemática Zoológica. \\ *Autor correspondente: michelle.mollemberg@gmail.com
}

\begin{abstract}
Camarões Macrobrachium Spence Bate, 1868 são caracterizados por ampla distribuição mundial em águas doces e estuarinas das regiões tropicais e subtropicais. No geral é um grupo amplamente estudado, porém, as informações sobre a distribuição geográfica dos camarões de água doce no Brasil, muitas vezes, não são documentadas. O que em alguns casos, pode até mesmo acarretar em interpretações errôneas da área de distribuição dessas espécies. No presente estudo registramos a ocorrência de quatro espécies de Macrobrachium

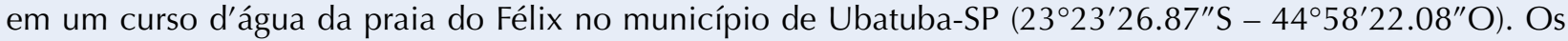
espécimes foram coletados nos dias 22 de fevereiro e 11 de abril de 2016, no período noturno. Foi analisado um trecho de aproximadamente $50 \mathrm{~m}$ do curso d'água (entre o início da praia até o desaguar no mar), com $30 \mathrm{~cm}$ de profundidade máxima e a maior distância entre as margens de $1 \mathrm{~m}$. Os espécimes capturados foram anestesiados em gelo, conservados em etanol a 70\%, identificados e depositados na coleção do Laboratório de Sistemática Zoologia (LSZ) da Universidade do Sagrado Coração, Bauru, São Paulo. No total foram encontrados onze indivíduos de quatro espécies: Macrobrachium acanthurus (Wiegmann, 1836) (3 fêmeas ovígeras), M. carcinus (Linnaeus, 1758) (1 fêmea), M. nattereri (Heller, 1862) (1 macho e 1 fêmea ovígera) e M. olfersii (Wiegmann, 1836) (2 machos e 3 fêmeas ovígeras). O curso d'agua amostrado apresentou grande diversidade de espécies de Macrobrachium, além de características ideais para a ocorrência de outras espécies de água doce, como baixa salinidade (3ppm), disponibilidade de matéria orgânica, alimento e abrigo e boas condições para desova. No entanto, em nova amostragem em outubro de 2016, constatou-se que esse curso d'água não possui fluxo de água permanente e apresenta períodos de seca, o que comprometeu as espécies locais.
\end{abstract}

Palavras-chave: distribuição, Macrobrachium acanthurus, M. carcinus, M. nattereri, M. olfersii. 